\title{
Floor Crossing and Nascent Democracies - a Neglected Aspect of Electoral Systems? The Current South African Debate in the Light of the Indian Experience
}

\author{
By Clemens Spieß and Malte Pehl, Heidelberg
}

\section{Introduction}

This paper deals with an aspect of electoral systems, which has so far attracted less than overwhelming scholarly attention, although the political phenomenon linked to this aspect has haunted numerous post-colonial societies in their attempt to consolidate parliamentary democracy and still is of great significance as regards the bulk of Third Wave democracies: the question of 'floor crossing' or - in a less procedural sense - 'politics of defection' to use the famous phrase, with which Sub hash Kashyap ${ }^{1}$ in one of the rare scholarly attempts to tackle the phenomenon analytically was describing the staggering number of changes of party affiliation or allegiance by elected representatives that seriously altered the course of post-independent India's evolution of party politics and the party system. ${ }^{2}$

While almost all features and technical details of electoral systems have been covered by the vast literature on constitutional engineering for nascent democracies ${ }^{3}$, the question

Kashyap, Subhash, 'The Anti-Defection Law - Premises, Provisions and Problems', in: Journal of Parliamentary Information, 35 (1), 1989, pp.9-27.

In this paper the terms floor crossing and defection are used synonymously. Strictly speaking, the term floor crossing - deriving from the spatial distribution of government and opposition in the British House of Commons - is confined to the movement of a legislator from the opposition to the government or vice versa. Since defections involving other constituents of the party system /parliament than government and/or opposition can have serious consequences as well and any democratically established anti-defection legislation confined to the meaning of floor crossing in strictu sensu would be discriminatory and violative of constitutional rationality in terms of equality before the law, it seems reasonable to refer to both terms synonymously.

In the South African context, for example, the academic literature on constitutional engineering with special regard to the electoral system is abundant; see Lijphart, Arend, 'Prospects for Power Sharing in the New South Africa', in: A. Reynolds (ed.), Election '94 South Africa. The campaigns, results and future prospects. Cape Town and Johannesburg, 1994, pp. 221-233, as main reference; see also Horowitz, Donald L., A Democratic South Africa? Constitutional Engineering in a Divided South Africa. Berkeley, 1991, for the argument of Lijphart's main opponent. A comprehensive summary of the scholarly debate about the pros and cons of the various electoral systems with regard to South Africa and the Southern African region is given in Reynolds, Andrew, Electoral Systems and Democratization in Southern Africa. Oxford, 1999; an overview of 
whether floor crossing should be allowed in the name of the individual parliamentarian's 'freedom of conscience' and primary accountability, or, whether anti-defection regulations should be imposed in order to guarantee regime stability and proportional representation rarely finds its way into academic research and scholarly debate going beyond everyday political discussion and public discourse.

This is striking, for (the politics of) floor crossing/defection can and do act in a distorting and discriminatory manner as regards electoral outcomes with often devastating consequences. On the other hand, where anti-defection legislation is imposed and floor crossing becomes a matter of legal control, very often a mockery is made out of the Burkean notion of a parliamentarian's independence and freedom of conscience. ${ }^{4}$

Defections were, for example, for the most part responsible for the decline of Congress dominance in India from the late 1960s onwards as well as for the period of fragile coalition arrangements characterising the country's political process since the mid-1980s despite the introduction of an anti-defection law in 1985; and the recent passing of legislation to permit (limited) floor crossing in South Africa - after a period wherein an anti-defection clause had minimised any autonomy, incentive and willingness of parliamentarians to break with their loyalty to the party - was brought about by and has resulted in a strange coalition of the African National Congress (ANC) and the New National Party (NNP) - the latter being the party whose antecedent had invented and implemented apartheid - thus reinforcing the image and political structure of the country as an emerging one-party dominant state and dismantling the manipulative efforts of party elites to alter the 'rules of the game'.

the electoral reform debate in South Africa is given in Krennerich, Michael and Jacques de Ville, 'A Systematic View on the Electoral Reform Debate in South Africa', in: Verfassung und Recht in Übersee, 30 (1), 1997, pp. 26-41. For the Indian case refer to Stuligross, David and Ashutosh Varshney, 'Ethnic Diversities, Constitutional Design and Public Policies in India', in: A. Reynolds $(e d)$. The Architecture of Democracy - Constitutional Design, Conflict Management, and Democracy. Oxford, 2002, pp. 429-458 and Singh, L.P., Electoral Reform: Problems and Suggested Solutions, New Delhi, 1986. Also, see the arguments contained in the review by the Government of India, National Commission to Review the Working of the Constitution. Review of the Working of Political Parties Especially in Relation to Elections and Reform Options: A Consultation Paper, New Delhi, 2001.

4 Burke, Edmund, 'Speech to the electors of Bristol', in: Hill, B.W. (ed.), Edmund Burke on Government, Politics and Society, New York, 1975, p. 157. Additionally, rigid anti-defection legislation stands in the way of party splits and mergers on (justified) ideological grounds as it may rule out a necessary reshuffling of party political convictions and policy orientations due to changing conditions and opportunities in political life during a legislative period. 
Of course, party cohesion and discipline within certain limits is seen as a necessary condition for a smooth functioning of parliamentary systems. As Bowler, Farrell and Katz ${ }^{5}$ rightly argue, "Cohesion and discipline matter in the daily running of parliaments. The maintenance of a cohesive voting bloc inside a legislative body is a crucially important feature of parliamentary life. Without the existence of a readily identifiable bloc of governing politicians, the accountability of the executive to both legislature and voters fall flat. It can be seen, then, as a necessary condition for the existence of responsible party government."

However, tightened and legally established party control over elected representatives can be dangerous and undermines a key principle of parliamentary democracy and competitiveness, namely the latent threat to and control of the government by the possibility of its followers crossing the floor.

Floor crossing is less of a problem in advanced western democracies where no anti-defection regulation prevails ${ }^{6}$ and other avenues are available and sufficient to uphold party discipline. $^{7}$ While defections take place in these democracies as well ${ }^{8}$, floor crossing seldom reaches the dangerous proportions one encounters in nascent or post-colonial democracies. This is hardly surprising, since it would have been presumptuous to expect parliamentary and party political practice in nascent and/or post-colonial societies, where modern institutions are to some extent 'imported', to immediately adjust their shape and role to the profile and mechanisms developed during the (long) evolution of their western counterparts.

In a context where relevant loyalties and identities have to be produced afresh, conflict and contestation have to be co-ordinated along so far unfamiliar institutional lines, and mobili-

Bowler, Shawn, David Farrell and Richard Katz, 'Party Cohesion, Party Discipline and Parliaments', in: Bowler, Shawn, David Farrell and Richard Katz (eds.), Party Discipline and Parliamentary Government, Columbus, 1999, p.3.

6 Among advanced democracies only New Zealand has so far implemented anti-defection legislation.

7 In (Westminster based) parliamentary systems these include, for example, the disciplining effect of 'whips' or other officers responsible for keeping party members informed and demanding them to 'toe the party line', sometimes under threat of expulsion from the party organisation or denial/ reduction of speaking or question time. Other means of upholding party discipline known to all parliamentary systems include the denial of promotions, the cutting of resources or, ultimately, withdrawing of support in the pre-selection of the seat at the next election and expulsion from the party (Miskin, Sarah, Politician Overboard: Jumping the Party Ship. Research Paper No. 4 (20022003) of the Information and Research Services, Canberra, 2003, p.10).

In some of them, like, for example Italy and France, the practice of floor crossing/defections has seriously undermined government stability and party system institutionalisation. However, both of them have refrained from introducing any kind of anti-defection legislation. 
sation and participation have to be channelled for the first time, the room to manoeuvre for political actors is naturally bigger, the institutional rules of the (democratic) game are not that clear or still in a state of flux, and the challenges for the representational system are different from those in the established democracies of western provenience.

Most often however, accounts of floor crossing and defections in nascent and/or post-colonial democracies refer solely to the specific political culture prevailing in these countries, which is said to be especially prone to political opportunism and personalismo, and to their low level of democratic habituation - without any serious consideration of the underlying normative aspects the debate of floor crossing vs. anti-defection legislation entails and of the (party) political context, in which the problem of defections is ensconced.

This paper aims to look for other reasons as to why the relationship between floor crossing and the principle of representative democracy in the context of nascent and/or post-colonial democracies is much more intricate than that any simple reference to a particular political culture and cultural essentialism could grasp its logic. Taking the partisan nature of most incidents of floor crossing and most changes of the electoral system with regard to the problem of defections as a given, it is argued that 1) the nature of the electoral system prevailing in a given country determines the way and manner whereby the phenomenon of floor crossing has to be handled, and 2) that variations in the level, consequences and management of defections depend on party elites' perception and strategic assessment of the distribution of party political power or, for that matter, the configuration of the party system.

But before going into a discussion of these arguments, an outline of the political background, the electoral system and the rules governing floor crossing in the two empirical contexts under examination is given including an assessment of the party political configuration leading to and the political consequences brought about by the attempts to contain floor crossing and to undermine existing anti-defection regulations respectively.

A comparison between India, which had started her democratic career with no constitutional provision to prohibit floor crossing and had introduced an anti-defection law in 1985 ruling out individual defections but still permitting en bloc defections, and South Africa, where an initial anti-defection clause had been gradually undermined in the course of 2002 to the point that floor crossing is now possible at all three legislative levels within specified time frames, can then be a telling exploration as to a) what the Indian experience may hold as a lesson for the current debate in South Africa, b) as to what extent the difference in the two respective electoral systems (a simple plurality constituency system in India and a closed list proportional representation system in South Africa) proscribes a different approach to the debate of floor crossing vs. anti-defection laws anyway and c) as to why the nature and cause of defections and attempts at their containment is highly dependent on the 
specific configuration of the one-dominant party system in the two countries. Additionally, the question has to be raised as to how effective anti-defection regulations really are. India, for example, has experienced more party jumping on average (through legally established en bloc defection) since introducing anti-defection legislation than it encountered before, and in South Africa the anti-defection clause prevailing until last year did not prevent the ANC from 'arranging' floor crossing of two parliamentarians thus ignoring the constitutional provisions.

\section{The Indian Experience}

\section{The Political Background}

India has to be subsumed under the rubric of successfully democratized post-colonial states, the authoritarian interlude of the Emergency (1975-77), the growing problems of corruption and criminalization of politics (not altogether unknown in other Western and non-Western contexts) as well as the failure of democratic government in some parts of India (e.g. Kashmir or Assam) notwithstanding.

Political parties are thriving in India's federal political system, with the Election Commission of India recognizing 8 national and 48 state parties ${ }^{10}$, competing for electoral offices in the last General Elections to the lower house of the national parliament, the Lok Sabha, in 1999. Taking the party system as the focus of attention, Indian politics has often been divided into two more or less distinct phases, the Congress and the post-Congress eras, respectively. During the first twenty years of independence, until 1967, the INC dominated Indian politics, governing both at the national level as well as in almost all states con-

As Lodge notes: "Strictly speaking, in the event of any vacancy parties are meant to replace resigned or deceased representatives with people from the original list in order of their nomination: in practice all parties have ignored this constitutional stipulation and parliamentarians have been moved between the national and provincial legislatures, as well as in and out of the public service and the party bureaucracies irrespective of their presence or positions on lists. This enabled the ANC in the last week of the 1999 parliamentary session to arrange a floor crossing in all but name when two defecting legislators from opposition parties were immediately inducted as ANC MPs." See Lodge, Tom, Consolidating Democracy - South Africa's Second Popular Election, Johannesburg, 1999, p.21.

10

National parties are such parties, which are registered with and recognized as such by the Election Commission of India according to standards set by the Commission. Regional parties are recognized by the Election Commission of India as such under its regulations accordingly. Whether a party is recognized as a national, a state or a registered-unrecognized party depends for example on the duration of its previous political activity and the success in previous elections and determines its access to broadcasting time on public radio and television, its right to an exclusive nation-wide or state-wide party symbol or other privileges. The data was taken from the Election Commission webpage at www.eci.gov.in/ge1999/parties/index.htm. 
tinuously. Although its dominance at the all-India level continued more or less until 1989, with a brief interlude of two Janata Party governments from 1977 to 1979, 1967 does mark a turning point with the INC losing power in several states for the first time, which ultimately led to the split in the Congress Party in 1969. From this time onward, the opposition parties were able to move from their status as mere 'parties of pressure' ${ }^{11}$ vis-à-vis the INC to a position as a credible alternative, first at the state level and later (from the 1977 General Elections onward) also at the national level. Since then, the Indian party system has moved from 'one-party dominance' 12 to increased pluralism, including growing regionalisation and with a strong tendency of parties having to rely almost always on internally diverse coalitions in order to be able to form governments at all levels of the system. The electoral dominance of the Congress Party at the national level was far from over, however, after 1967, especially when taking into consideration the landslide victory at the General Elections 1984 against the general trend, which brought the INC more than 76 percent of seats in the Lok Sabha.

The government coalition which assumed power at the national level after the elections in 1999, the National Democratic Alliance (NDA), led by the Bharatiya Janata Party (BJP), consisted of a large number of regional parties ${ }^{13}$ (including among others the Janata Dal (United), Telugu Desam Party, Akali Dal and Shiv Sena) and won 302 out of the total 543 parliamentary seats in the last national elections to the Lok Sabha. After the withdrawal of the Telugu Desam Party from the coalition in 2002, the Bahujan Samaj Party joined the NDA. The debate around defections in India needs to be seen in the light of this environment of fragmentation of the party system and the concomitant fragmentation within legislative bodies. Coalition governments, both at the state and at the national levels, have been vulnerable in the past to the phenomena of defections as well as to the withdrawal of support from entire legislative parties. Both of these phenomena have led to considerable governmental instability, in particular at the state level ${ }^{14}$, which is widely regarded as

The term 'one-party-dominance', connotative of the main conceptual and analytical features of the initial phase of party system development in India, was first introduced to the scholarly community by Rajni Kothari (Kothari, Rajni, Politics in India, New Delhi, 1985 [1970], p.161). Independently, W. H. Morris-Jones came to similar conclusions about the conceptual and analytical nature of India's system of one-party-dominance, and, often used the same terminology as Kothari. See Morris-Jones, W. H., 'The Indian Congress Party: A Dilemma of Dominance', in: Modern Asian Studies. 1 (2) 1967, pp.109-132.

'Regional party' refers to the regional character of the electoral success of a party, not to its status under the Election Commission of India's regulations for the registration of political parties.

14

See Mitra, Subrata K., Governmental Instability in Indian States, Delhi, 1978 or Brass, Paul R., 'Party Systems and Governmental Stability', in: American Political Science Review, 71 (1977), pp.1384-1405 as early examples of studies of the first wave of coalition governments and their stability in Indian states. 
undesirable. Another issue in this connection is that of a corruption or criminalization of politics, which is said to have led to defectors being paid from outside the parliamentary system or to being rewarded for floor crossing in the shape of ministerial posts (Wilkinson 2001). In addition, an increasing number of splits in legislative parties due to bulk defections have further fuelled the debate on the necessity of reform of the current anti-defection legislation and electoral laws.

Basic outline of India's electoral system and evolution of the country's anti-defection legislation

The first institutional component in India's political system, which will be discussed here, is the Indian electoral system. Both the lower house of the national Parliament, the Lok Sabha, as well as the Legislative Assemblies (Vidhan Sabhas) in the Indian States and the Union Territory of Pondicherry, as well as in the National Capital Territory of Delhi are elected according to the first-past-the-post system through single-member constituencies. Currently, the largest state assembly is that of Uttar Pradesh with 403 seats, the smallest state assemblies are those of Sikkim with 32 and Goa with 40 seats (the Union Territory of Pondicherry has an even smaller assembly with only 30 seats at present). The Lok Sabha comprises 545 seats, out of which 530 are elected from the Indian states, 13 are currently elected in the Union Territories and two members are nominated by the President from the Anglo-Indian community (Articles 81 and 331 of the Indian Constitution [as amended up to the Fifty-Second Amendment] and the Representation of the People Act, 1950). The elections are held on the basis of universal adult franchise, with the voting age being 18 years. The total electorate in India exceeds 600 million by far and voter turnout has typically been between 50 and 65 percent in national elections.

The Lok Sabha and the state assembly elections can be entered into by candidates who are affiliated with and have received the ticket to run on behalf of a political party, but also by independent candidates. Although independent candidates regularly outnumber party candidates, the Election Commission of India's statistics indicate a far greater electoral success of party-affiliated candidates across the board ${ }^{15}$.

The other institutional characteristic pertinent to our examination is the existence of antidefection measures within the Indian constitutional structure as an example of constitutional engineering. Taking this institutional feature, as embodied in the structure of the law, as the determinant, Indian post-Independence politics could be separated into two phases, 
with the possibility of a third phase commencing in 2003 if the legislation currently under debate in the Lok Sabha does become constitutional law.

The first phase would then be from 1950 to 1985 , when no legislation existed with respect to the issue of floor crossing (both in the shape of a change of affiliation of a member of parliament to a certain legislative party and in the form of voting against the party line). During this phase, members of the Lok Sabha and the state assemblies were free to change their party affiliation without any restrictions and without any threat to their membership of the respective legislative bodies. It was during the first much publicised wave of defections, that from 1967 to 1971, almost 2,000 cases of defection occurred from among the 4,000 combined members of the Lok Sabha and the Legislative Assemblies in the States and Union Territories. Out of the 210 cases of defection which occurred during the year 19671968 in various Indian states, in 116 cases the defector was later included in the Council of Ministers ${ }^{16}$. The first initiative to ban defections was taken with the Constitution (Thirtysecond Amendment) Bill, 1973, which lapsed, however, after extensive debate in a Joint Committee of both Houses of Parliament in $1977 .^{17}$

The second phase in Indian politics would consequently be that from 1985 to 2003, after the introduction of anti-defection legislation in the form of the Tenth Schedule to the Indian Constitution by the Constitution (Fifty-second Amendment) Act, 1985. Paragraph 2, clause 1 of the Tenth Schedule, in connection with Article 102 (2) of the Indian Constitution (as amended up to the Fifty-Second Amendment), stipulates that a member (whether elected as a candidate set up by a political party, as an independent or nominated member) of either House of Parliament or any Legislative Assembly in the said States or Union Territories will be disqualified if he/she gives up voluntarily his membership of the political party he belonged to at the time of election, or if he/she votes or abstains from voting contrary to the directions of his/her party or a person authorized by that party to give such directions without obtaining prior or subsequent permission from that party. The same sanction is foreseen in Paragraph 2, clauses 2 and 3 of the Tenth Schedule for defectors who were elected as independent candidates and who later join a political party, or nominated members who join a political party after six months from the date of his nomination. Exceptions from this rule are provided by Paragraph 3, which stipulates that defecting members shall not be disqualified if they claim to constitute a group of defectors as a result of a split which occurred in the original party and where this group consists of no less than one third of the

See Kashyap, Subhash C., 'The Anti-Defection Law - Premises, Provisions and Problems', in: Journal of Parliamentary Information, 35 (1) 1989, p.10 for details and the data on this era of defections. tion, March, 38 (1) 1992, p.32 for a detailed account of this initiative during the first heyday of defection politics. 
original legislative party to which they belonged. Another exception is contained in Paragraph 4 (1) of the Tenth Schedule (Constitution of India), which exempts such members from disqualification in cases where his/her political party merges with another political party and he/she claims membership of that new party or in cases where he/she does not accept the merger and does not join the new political party, but opts to function as a separate group along with other members of his/her former political party. The final decision regarding disputes around disqualifications is conferred upon the Speakers of the respective legislative bodies by Paragraph 6 of Schedule X. Paragraph 7 of the same Schedule sought to bar jurisdiction of the courts from all disputes over disqualifications according to the Tenth Schedule. However, in a decision dating from 1992, the Indian Supreme Court in Kihota Hollohon vs Zachilhu and Others declared Paragraph 7 to be unconstitutional ${ }^{18}$.

The possible third phase could be about to commence in 2003 if the Constitution (Ninetyseventh Amendment) Bill, 2003 is passed in Parliament, as introduced by the NDA government. This Bill seeks to modify the Tenth Schedule by omitting Paragraph 3. A defector would henceforth be disqualified from membership in the legislature until he contests fresh elections. Additionally, defectors would be barred from holding any ministerial posts for the rest of the term of existence of the legislature or until the next elections, whichever is earlier. This bill thus takes up the recommendations of the Dinesh Goswami Committee of 1990 and from the Report of the National Commission to Review the Working of the Constitution, 2002. Another measure, currently in the Lok Sabha for debate, is the proposal of the Indian government to limit the size of the Councils of Ministers to $10 \%$ of the number of seats of the Legislative Assemblies in each State which has a unicameral legislature, and to $10 \%$ of the combined strength of both chambers in States with bicameral legislatures and at the Union level. If these amendments are passed, floor crossing would thus be carrying the price-tag of losing membership of the respective legislative body, irrespective of whether it occurs individually or en bloc. It would be less likely to be rewarded with a post on the Council of Ministers.

\section{The Political Consequences}

In the absence of anti-defection legislation before 1985, during the first phase of 'politics of defection', defections were heavily influenced by the structure of the Indian party system at the time and mainly benefited the Congress Party ${ }^{19}$. Contrary, to what would conventionally be assumed after the introduction of anti-defection legislation, on average more defec- 
tions have occurred after the introduction of the Tenth Schedule than before ${ }^{20}$. Particularly small States like Goa still suffer from bulk defections permitted under Paragraph 3 of Schedule X. Due to the frequent floor crossing, Goa has so far had 13 Chief Ministers in the last twelve years. A similar scenario can be found in some North-eastern Indian States with relatively small populations and State Assemblies. The logic of numbers seems to dictate that bulk defections are relatively easily organized in such small Assemblies but this is by no means a sufficient explanatory factor. Also Uttar Pradesh has witnessed numerous defections despite its comparatively large Legislative Assembly. And even at the Union level the government of Prime Minister V.P. Singh was voted out of office in a vote of no confidence in November 1990 after the defection of 37 members of the Janata Dal legislative party. This brought a minority government under Prime Minister Chandra Shekhar to power with the support of the Congress (I) legislative party ${ }^{21}$. Another effect of the permissibility of en bloc defections under the current law has been the further fragmentation of the party system with political leaders virtually being rewarded for engineering a split in their former legislative party in order to voice their dissent on certain matters. This is so, since their individual floor crossing in cases of disagreement on ideological or policy matters carries too expensive a price-tag in the form of a disqualification from membership. This fragmentation is more visible at the state level legislatures than at the national level, however. Also, the decisions of Speakers of legislative bodies, who are charged with the final decision on disqualifications in the case of State legislatures has occurred and led to considerable controversy ${ }^{22}$. Overall, the result of this legislative engineering with respect to floor crossing has yielded mixed results, and is viewed as a failure in the eyes of many of those who see floor crossing as inherently dangerous.

As will be discussed later, the electoral system of a country and the way in which the debate about floor crossing evolves, are often intimately connected. However, this need not always be so, as the Indian case demonstrates. With a first-past-the-post electoral system in place, one would expect in theory the independence and accountability of a Member of Parliament (MP) towards his/her constituency to be one of the principles most emphasized in the debate. In India, however, most candidates heavily rely on the support and their association with a political party for their electoral success. The relatively negligible success of independent candidates at the national level, which we touched upon earlier, may be regarded

Government of India, Report of the National Commission to Review the Working of the Constitution: Review of the Working of Political Parties Especially in Relation to Elections and Reform Options: A Consultation Paper, New Delhi, Section 4.18.1.

For a more detailed account of these events, refer to Gehlot, N.S., 'The Anti-Defection Act, 1985 And The Role Of The Speaker', in: The Indian Journal of Political Science, 52 (1), 1991, p.333.

22

Paragraph 6, Schedule X. See Gehlot, N.S., 'The Anti-Defection Act, 1985 And The Role Of The Speaker', in: The Indian Journal of Political Science, 52 (1), 1991 p.332, for a discussion of several cases of incoherent decisions by Speakers within the same legislature or across legislatures. 
as one indicator of this phenomenon. Consequently, the much publicised debate around floor crossing has in the past almost always been in favour of party discipline and opposed to defections.

In a system based on proportional representation (PR), one would expect the party to play an even more important role and anti-defection legislation would at a first glance be much more relevant and theoretically legitimate in such a system where candidates are elected on a list basis. Consequently, in view of the high number of defections in India in the first half of the 1970s, L.K. Advani, currently a Minister in the NDA government, proposed the introduction of a PR voting system as early as 1974 in order to give parties greater power members of legislatures through the nomination process for the party lists ${ }^{23}$. Additionally, if the Constitution (Ninety-seventh Amendment) Bill, 2003 becomes law, India, despite employing a first-past-the-post voting system, would move away completely from the ideal of an 'independently and critically thinking' model MP in its institutional framework (both in terms of voting in legislatures and in terms of changing party affiliations in cases of gross disagreements) by institutionalising loss of membership in both, cases of individual and bulk defections. On the other hand, the second legislative measure, namely to limit the size of councils of ministers, which is meant to reduce the possibility of rewarding defectors, would also hardly solve the problem of the high number of bulk defections. If the size were really limited at the level, which is currently being proposed in the debate, this would still allow for around 80 members in the Union government's Council of Ministers, a number even higher than the actual number of members today. Only in the case of small State legislatures this measure is likely to have an impact.

In consequence, it could be argued that India, in order to curb defections effectively, might adopt a PR or semi-PR voting system, as has also been suggested by several commissions on electoral reforms in the past, if almost all parties currently agree that MPs and Members of Legislative Assemblies (MLAs) should have as little opportunity to disagree with the party leadership as possible. Adopting a pure proportional representation electoral system, however, could have serious implications for Indian politics. In the current system, extensive inter-group bargaining takes place before a candidate can be sure to receive support from enough group leaderships of communities within his constituency to secure a victory in his/her constituency. If a pure PR system were adopted, these negotiation processes would likely not continue. In a democracy with an electorate which is as ethnically, religiously and linguistically diverse (even within individual constituencies) and with a population where group identity is still vastly more important than individual identity as is the case in India, these processes of negotiation have been an important stabilizing factor in politics in the past. 
In view of the contradicting pulls within the Indian electoral system and the anti-defection legislation, and in view of the past and current debates in India, we shall now turn to the examination of the South African context, which presents us with an electoral system, a debate on defections and a party system quite distinct from those in India.

\section{The Current Debate in South Africa}

\section{Political background}

The current debate about floor crossing in South Africa is closely tied to the configuration of the country's party system prevailing and the recent reshuffling of opposition forces. The ANC's dominance in the party system and parliament is firmly established. In the two postapartheid general elections of 1994 and 1999 the ANC won an overwhelming share of the popular vote $(62,65 \%$ and $66,35 \%$ respectively) and only narrowly missed a two-thirds majority necessary to amend the constitution. The overarching feature of opposition parties is one of acute fragmentation. In the shadow of the ANC, they have basically two options: Either they try to collaborate with the ANC in order to 'share the fruits of power' as does the Inkatha Freedom Party (IFP) at the national and regional level and a bulk of smaller parties at the local level, or they engage in 'robust' opposition like the two main 'white' opposition parties, the Democratic Party (DP) and, until recently, the NP/New National Party (NNP) ${ }^{24}$. However, due to their regional strongholds based on regionally and demographically concentrated constituencies, the ANC was not able to capture two of the country's nine provincial legislatures electorally. In the Western Cape legislative power went to an NNP/DP coalition and in KwaZulu-Natal the Zulu-based IFP shares provincial government with the DA.

In a bid to concentrate their strength, DP and NNP were joining together as the $\mathrm{DA}^{25}$ in 2000 and quite successfully contested the local elections in the same year with a unified electoral list. ${ }^{26}$ In November 2001, however, the NNP withdrew participation in the electoral arrangement because of factional infighting over appointments, the party's future trajectory and basic values. In reality however, the NNP had already begun to work towards a tacit agreement with the ANC aimed at expanding the ANC's majority at the national level, helping it to acquire absolute majorities in the Western Cape and KwaZulu-Natal as well as in most Municipal Councils (especially Cape Town) in exchange for participation in ANC-led governments at the local and provincial level.

The NP was renamed shortly before the elections of 1999.

25

The third component of the DA was the numerically negligible Federal Alliance (FA).

26

On average the DA won about $22 \%$ of the votes in the local elections.
} 
The problem now was to change the existing electoral law, which entailed an anti-defection clause, in such a manner that it would allow floor crossing in order to engineer the desired majorities and coalitions. The additional problem at the local level, where there was no distinction between DP and NNP representatives anymore, was to render it possible for the former NNP representatives of the DA to regain their original party affiliation.

\section{Basic outline of South Africa's electoral system and evolution of the country's anti- defection legislation}

In South Africa, an electoral system of proportional representation is prescribed for the composition of all main representative bodies, primarily the National Assembly and the Provincial Legislatures. At the local level a mixed system of proportional representation and constituency-based plurality voting can prevail. The 1996 Constitution, like the 1993 (interim) Constitution, requires a structure, which results "in general, in proportional representation" (RSA 1993: Schedule 2, RSA 1996: Sec 46 (1d)) Interestingly enough, the ANC opted for an electoral system that ran counter to its partisan interests, for a first-past-thepost system would have clearly benefited the ANC as the putative majority party in most of the constituencies. ${ }^{27}$

The option for an electoral system of proportional representation, however, can be seen either as an example of the ANC's goodwill for compromise ${ }^{28}$ or ideological commitment to integrate as many societal groups as possible into the political system ${ }^{29}$, or, as an indication that the ANC - cognisant of the fact that it would yield enough electoral support to overcome the power-sharing requirements - was, nevertheless, geared towards establishing majority rule ${ }^{30}$, in other words, to turn South Africa into what was once termed by Nelson

The ANC's initial preference was a plurality system (Asmal 1988). The constitutional provisions regarding the electoral system laid down in the interim constitution have been retained with the final constitution adopted in 1996.

Lijphart, Arend, 'Prospects for Power Sharing in the New South Africa', in: Reynolds, Andrew (ed.). Election '94 South Africa. The campaigns, results and future prospects. Cape Town and Johannesburg 1994, p.229. He even goes further, stating that „The ANC's high-minded stance on PR runs completely counter to the conventional wisdom that political parties act on the basis of their narrow partisan self-interests - putting political scientists who operate on this assumption to shame!"

See, for example, Sisk, Timothy D., Electoral System Choice in South Africa. Paper prepared for the IPSA-Congress, Berlin, August 21-25, 1994, p.12, and Pottie, David, 'The Electoral System and Opposition Parties in South Africa', in: Konrad-Adenauer-Stiftung (ed.). Seminar Report. Opposition in South Africa's New Democracy. Johannesburg, 2001, p.154.

Mattes, Robert. 'The Road to Democracy: From 2 February 1990 to 27 April 1994', in: Reynolds, Andrew (ed.). Election '94 South Africa. The campaigns, results and future prospects. Cape Town 
Mandela as a "normal democracy as the world knows it". 31 And the recent floor crossing legislation confirms this instrumental view adopted by the ANC when dealing with the country's institutional/electoral arrangement.

The two institutional features of the South African electoral system that are of importance for our purpose of exploring the cause, nature and implications of floor crossing and of the role of anti-defection legislation are the following (at the same time, these features do underpin the assumption that the choice for PR was as much deliberately guided by partisan interests as it was by more altruistic principles. ${ }^{32}$ ): Firstly, the specific PR system chosen is a closed list system (or 'pure proportional system'), which combines regional and national party lists and allocates seats among the competing parties according to their proportional entitlement to the 200 'regional' (those calculated on the basis of the respective party's vote share on the provincial level) and 200 'national' (those calculated on the basis of the respective party's total vote share) seats of the National Assembly using a Droop quota and the highest remainder principle. ${ }^{33}$ The same method applies to the Provincial Legislatures elections on the basis of one provincial list submitted by each party contesting the elections. Accordingly, there is much room to manoeuvre for the party leadership in determining who gets elected while, at the same time, the degree of individual accountability of MP's to their 'constituencies' is much less than it would have been the case in a plurality system $^{34}$. On the other hand, in terms of representativeness, inclusion ('drawing extremist parties into the mainstream of political life') and accessibility ('making people feel that their vote makes a difference') the South African electoral system clearly outperforms any plurality counterpart (Reynolds 1995).

and Johannesburg 1994, p.7, and Sisk, Timothy D., Democratisation in South Africa: The Elusive Social Contract, Princeton, p.190.

Quoted in Argus, November 5, 1991.

Whereas a consensus on PR, i.e. the principle of proportionality, was reached as early as 1991 and was codified in the ,Declaration of Intent' of the first CODESA bargaining forum, the debate about the concrete shape of the PR electoral system was much more controversial, see Sisk (1993).

To arrive at a distribution of National Assembly and Provincial Legislature seats in proportion to the respective party's share of the votes cast, a quota is determined by dividing the total number of votes cast in the election by the number of seats to be filled, plus one. The result is then rounded down to the nearest whole number. Then, one is added. Consequently, each party's total votes are to be divided by the quota - thus showing how many seats it is entitled to. The unallocated seats are distributed according to the principle of the highest remainder. If the number of unallocated seats is exceeding five, the additional seats are distributed according to the average number of votes per seat for each party; see EISA (1999: 4-8). The quota for a seat in the National Assembly was 48.712 votes in 1994 (own calculations) and 39.844 votes in 1999 (Electoral Institute of Southern Africa (EISA) National \& Provincial Election Results. South African Elections June 1999. Auckland Park, Johannesburg, p.16). 
At the local level every town or community is subsumed under the category of metropolitan, urban or rural and divided into several wards. Here proportional representation may coexist with ward-based plurality voting of individual candidates, but in the end, elections are proscribed to result in proportional representation.

The vote takes place in large, multi-member districts and there is no threshold for parliamentary representation imposed apart from the effective (mathematically established) one arising out from the allotment of seats to the National Assembly, i.e. the Droop quota. As a result, small parties can rely on the electoral system to provide them seats in the parliament and, therefore, had always expressed preference for PR over any kind of plurality system (as did the NP and IFP for similar reasons, although they probably would have survived even the most rigid plurality system because of their regional strongholds in the provinces of KwaZulu-Natal and the Western Cape) ${ }^{35}$, whereas the large, multi-member electoral districts - in part a necessity given the combined regional and national party-list system furthermore put the emphasis in the voters' decision on the parties contesting the elections and not on individual candidates representing constituency-based interests. ${ }^{36}$

The second and most important institutional feature of the country's electoral system for our purpose is(are) of course the constitutional provision(s) dealing with the question of floor crossing. The interim Constitution of 1993 entailed an Anti-Defection Clause (Schedule 2, Clause 23A) stating that any representative would lose its mandate if he or she would cease to be a member of the party on whose list he or she was elected. The AntiDefection Clause had been retained with the final Constitution (The Constitution of the Republic of South Africa 1996, as adopted by the Constitutional Assembly on 8 May 1996, Act 108 of 1996, Schedule 6, Annexure A, Item 13) albeit as part of the transitional provisions and, as such, pending upon ordinary legislation without the need of a two-thirds

The extremely low threshold as well as the almost perfectly proportionate translation of votes into seats naturally minimises the incentives to form cross-party coalitions and increases the likelihood of party factions to split.

Additionally, a closed list PR system with large, multi-member electoral districts obviates the potential danger of gerrymandering in a constituency-based electoral system. Due to the separate ethnic/racial settlements and skewed local population distribution - an enduring legacy of racial segregation codified in the Group Areas Act repealed in 1991 - the large electoral districts, concomitant with administrative units, further political representation of all ethnic/racial groups and favour the moderate big parties. Since the single largest problem in the constitutional debates about the electoral system was voter accountability, many of the larger parties allocated constituencies to their members on an informal basis; see Beukman, Francois (NNP), 'The Implications of Current and Potential Future Electoral Options for Political Diversity and Broad Political Representation in Our Democratic Institutions. The NNP Perspective', in: Konrad-Adenauer-Stiftung (ed.). Seminar Report. The Future of South Africa's Constituency System. Johannesburg, 2000, p.37. 
majority as would have been the case with a constitutional amendment. ${ }^{37}$ There was no similar constitutional provision for the local level; here, a constitutional amendment would have been needed.

The combination of a closed list electoral system of proportional representation and an antidefection clause was established as a means to protect proportionality of the legislature as decided at elections and to protect multi-party democracy by reinforcing the position of smaller parties in the proportional system. On the other hand, as Welsh ${ }^{38}$ notes on the favourable effect of the anti-defection clause for the ANC in the context of South Africa's emerging one-party-dominant system: "(it) [the anti-defection law] gives the leadership a tight grip on the compilation of lists and ensures that, once elected, MPs toe the party line or face expulsion from Parliament."

On the $4^{\text {th }}$ of October 2002 now - after legislation had been passed by the combined parliamentary strength of the ANC, NNP and DA allowing floor crossing within specified window periods (15 days in the second and fourth year after an election) on all three governmental levels ${ }^{39}$ and after the opposition United Democratic Movement (UDM) had challenged the constitutionality of the legislation - the Constitutional Court declared that the 'floor crossing legislation' was constitutional but did not approve of the legislation to apply at the provincial and national level for procedural reasons, while allowing it to apply at the local level ${ }^{40}$. The floor crossing legislation entails an additional specification that confines floor crossing to the requirement that at least $10 \%$ of a party's representatives have to 'cross floor', but only after an exceptional and out-of-turn first window period immedi-

Moreover, the final Constitution provided for the possibility of passing a law that would allow for party mergers and splits in parliament without the respective representatives losing their seat/mandate.

Welsh, David, 'Government shifts on voting reform', in: Focus (Helen Suzman Foundation), 23, September, 2001 available online at: www.hsf.org.za/focus23/focus23welsh.html.

The Constitution of the Republic of South Africa Amendment Act (Act 18 of 2002), The Local Government: Municipal Structures Amendment Act (Act 20 of 2002), The Constitution of the Republic of South Africa Second Amendment Act (Act 21 of 2002), The Loss or Retention of Membership of National and Provincial Legislatures Act (Act 22 of 2002).

40

Knirsch, Thomas S. and Elisabeth Schwab, 'Floor Crossing - Parteiübertritte in Südafrika und ihre Auswirkungen auf die junge Demokratie', in: Konrad-Adenauer-Stiftung (KAS), Auslandsinformationen, 2 (11) 2002, p.52. Since legislation on floor crossing for the national and provincial level was passed in accordance with the transitional provisions of the Constitution (Membership Act) effective only up to the elections of 2004, the Constitutional Court came to the conclusion that making use of the Membership Act before 2004 was not appropriate. If legislation on floor crossing would have been subject to a Constitutional amendment, the National Assembly in all probability would not had any problem to get rid of the Anti-Defection-regulations altogether. In the case of the local level a constitutional amendment had taken place. 
ately following its commencement, during which the $10 \%$ requirements for defections or subdivisions will not apply.

Whereas floor crossing at the local level went ahead shortly after the judgement was handed down and within the designated window period, parliament redrafted legislation so as to conform to the court's requirements and, finally, the Constitution of South Africa Fourth Amendment Act was passed allowing floor crossing on the same line as for the local level for the provincial and national levels as well (except that no MP or MPL can become independent), including an initial $10 \%$ threshold-free window period of 15 days which was opening on March 28 this year. However, a legislator may only once 'cross floor' during a legislative period.

\section{Political consequences}

The floor crossing period at the local level had already altered the party political landscape tremendously. Altogether 555 councillors $(7 \%)$ changed party affiliation and a lot of local governments were toppled down, most important the municipality of Cape Town, which went to an ANC/NNP coalition. In terms of 'net gains/losses' the ANC was the definitive winner whereas the DA lost much of its NNP wing (well over half of the DA's councillors) as well as control of or participation in 19 municipal councils. The NNP regained 340 of the 612 former NNP members of the DA plus additional 14 from other parties and gained participation in 21 municipal councils as compared to the 15 once controlled by the DA.

Table 1: Control of Municipal Councils: Gains and Losses due to Floor Crossing in 2002

\begin{tabular}{|l|c|c|}
\hline Party & Gained & Lost \\
\hline DA & - & 15 \\
\hline ANC/NNP coalition & 20 & - \\
\hline ANC/NNP/IFP coalition & 1 & - \\
\hline ANC/DA coalition & - & 3 \\
\hline ANC/DA/IFP coalition & - & 1 \\
\hline ANC/IFP coalition & - & 1 \\
\hline IFP & - & 1 \\
\hline Total & 21 & 21 \\
\hline
\end{tabular}


Table 2: Councillors Gained and Lost due to Floor Crossing in 2002

\begin{tabular}{|l|c|c|}
\hline Party & Members Gained & Members Lost \\
\hline ANC & 128 & 16 \\
\hline DA & 17 & 417 \\
\hline NNP & 354 & 0 \\
\hline
\end{tabular}

Source: Independent Election Commission of South Africa: www.elections.org.za

The most important political consequence the 'quasi-removal' of the anti-defection clause ${ }^{41}$ at the national and provincial level brought about was that it "gave the ANC two of the three political domains denied to it by the voters in the 1999 elections, and almost gave it the third" "42 : a two-third majority in the National Assembly which is needed to amend the constitution, an absolute majority in the Western Cape Provincial Legislature, and in KwaZulu-Natal, the ANC would have taken provincial power as well were it not for the Constitutional Court making five legislators, who had defected to the ANC before the constitutional status of the floor crossing legislation was settled, lose their seat.

Table 3: Seat-wise Consequences of 2003 Floor Crossing at the National Level (main parties)

\begin{tabular}{|l|c|c|c|c|c|}
\hline \multicolumn{1}{|c|}{ Party } & $\begin{array}{c}\text { Seats after 1999 } \\
\text { Elections }\end{array}$ & \% of Seats & Defectors & After Floor Crossing & $\%$ of Seats \\
\hline ANC & 266 & 66.5 & 9 & 275 & 68.75 \\
\hline DP/DA & 38 & 9.5 & 8 & 46 & 11.5 \\
\hline IFP & 34 & 8.5 & $(3)$ & 31 & 7.75 \\
\hline NNP & 28 & 7.0 & $(8)$ & 20 & 5.0 \\
\hline UDM & 14 & 3.5 & $(9)$ & 4 & 1.0 \\
\hline
\end{tabular}

41 Legally, and anti-defection regulation still prevails, for floor crossing is only allowed within specified window periods and based on the $10 \%$ requirement.

42 Myburgh, James, 'Floor crossing adds new muscle to ANC', in: Focus (Helen Suzman Foundation), 30 April 2003, pp. 34-36, available online at: www.hsf.org.za/focus30/focus30myburgh. html. 
Table 4: Seat-wise Consequences of 2003 Floor Crossing at the Regional Level (main parties)

\begin{tabular}{|c|c|c|c|c|c|}
\hline KwaZulu-Natal & $\begin{array}{c}1999 \\
\text { Elections }\end{array}$ & $\%$ of Seats & Defectors & $\begin{array}{c}\text { After Floor } \\
\text { Crossing }\end{array}$ & $\%$ of Seats \\
\hline ANC & 32 & 40.0 & 3 & 35 & 43.75 \\
\hline IFP & 34 & 42.5 & (2) & 32 & 40.0 \\
\hline DP/DA & 7 & 8.75 & $(1)$ & 6 & 7.5 \\
\hline NNP & 3 & 3.75 & (1) & 2 & 2.5 \\
\hline \multicolumn{6}{|l|}{ Western Cape } \\
\hline ANC & 18 & 42.86 & 4 & 22 & 52.38 \\
\hline DP/DA & 5 & 11.9 & 2 & 7 & 16.67 \\
\hline NNP & 17 & 40.48 & (6) & 10 & 23.81 \\
\hline
\end{tabular}

Source: Independent Election Commission of South Africa: www.elections.org.za

Apart from the party-political realignments taking place, five new parties were formed as a result of the floor crossing window period, thus reinforcing opposition fragmentation even more. The party most heavily affected by defections was the UDM, which was previously considered to be a serious upcoming contender of the ANC - at least in the latter's perception.

Additionally, recent survey data indicate that there was no significant mid-term realignment of party support and sentiment - contrary to the ANC's postulation and the Constitutional Court's argument that there had been a shift in public opinion - manifest in the split of the DA - and that therefore the floor crossing legislation and the lifting of the $10 \%$ requirement in the initial floor crossing window periods were justified. What is evident from the survey data is that an alienation of voters had taken place, especially in the provinces most affected by defections - The Western Cape and KwaZulu-Natal. Here, one third of respondents (32\% and 27\% respectively) said they would not vote if an election were held tomorrow, a considerable higher figure than in any previous opinion poll (Afrobarometer June 2003 ) ${ }^{43}$.

Hence, the main arguments of the debate about the floor crossing legislation and its implications revolved around the partisan nature of the ANC's effort to remove the anti-defec- 
tion clause. Whereas most observers concede that the anti-defection clause in combination with the list system of proportional representation had given the ANC party leadership too much power over its public representatives, the floor crossing legislation has enabled the ANC to foster its dominant position in the political and party system by means of changing the proportionality of the elected parliament. Moreover, because of the $10 \%$ requirement in addition to the governing/dominant party's advantage as regards attracting defectors and preventing own party members from crossing the floor using state patronage, the floor crossing legislation has made it very unlikely that there will be many defections from the ANC to smaller parties. The question of floor crossing vs. anti-defection legislation is thereby ensconced in a general debate about a reform of the overall current electoral system (the main point being the introduction of a constituency-based system), which has been going on right from the elections of 1994 and has gained momentum anew. Currently, a commission under the leadership of Frederik van Zyl Slabbert, former President of the Progressive Party (PP), is working on a draft suggesting substantial changes of the current system, which shall be considered for legislation before the elections of 2004.

\section{Floor Crossing vs. Anti-Defection Laws: The Importance of the Electoral System}

Before going into the discussion of the conceptual issues surrounding floor crossing and anti-defection laws in the context of electoral systems, it has to be settled what counts as a defection for - apparent from the preceding - there are competing ideas as to what constitutes the change of party affiliation/floor crossing/defection in a legal as well as a moral sense $^{44}$. The first distinction has to be made between defection and dissent. Is voting against the own party already an incident of defection ore merely the legitimate right of a legislator to express his/her dissent with the party line? Morally, the latter should be considered as being part and parcel of a parliamentarian's freedom of opinion and expression. Legally, however, India's anti-defection law includes 'voting in the House contrary to any direction of the party' the voter belongs to and even abstention from voting contrary to the party's directive as a reason for disqualification on the grounds of defection. Obviously, the aim of this rigid interpretation of defection is to prevent a legislator from staying with a party while continuously opposing its decisions, but it gives the party organisation a readymade disciplinary tool at hand to stifle dissent ${ }^{45}$.

This paper deals with sitting politicians only, not with party members as such.

45

The problem of interpretation is even more complicated. As Miskin, Sarah, Politician Overboard: Jumping the Party Ship. Research Paper No. 4 (2002-2003) of the Information and Research Services. Australia: Department of the Parliamentary Library, 2003, p. ii, notes: „Such a law [an antidefection law, the authors] may provide the incentive to stay within the party and agitate - to be a ,politician-in-exile', so to speak. Of course, a party can expel a dissenting, disloyal politician from its ranks, but would this count as defection in terms of the legislation? To be effective, the law would have to allow for expulsion from the party to count as a defection, but this opens a new 
A second clarification is needed to determine the status of independents with regard to floor crossing and/or anti-defection laws. This aspect is already closely related to the electoral system prevailing in a given polity and the (constitutional) status of political parties. Whereas most constituency based plurality systems (like India's) rest on individual candidatures and therefore give independents, in theory at least, the opportunity to contest elections, list systems (which are almost always electoral systems of proportional representation or combined systems comprising an element of proportional representation) give political parties a position of primacy to the extent that often no independents are allowed to take part in electoral competition as is the case in South Africa at the national and provincial level. For the sake of equality before the law, any provision for floor crossing or any antidefection legislation in a system comprising independent candidatures must therefore also take into account the role of independents and determine the way and manner whereby the change of affiliation from independent to party platform and vice versa has to be handled ${ }^{46}$.

A third distinction has to be made between individual and mass or en bloc defection, the latter being commonly referred to as 'merger' or 'split'. Whereas, at first sight, this distinction seems to be discriminating against the principle of constitutional rationality, the rationale for this distinction may be held acceptable on grounds of political morality. As India's Supreme Court pointed out in Kihota Hollohon with regard to the distinction between individual defections and splits and the constitutionality of this distinction in the 1985 anti-defection legislation ${ }^{47}$ :

"The underlying premise in declaring an individual act of defection as forbidden is that lure of office or money could be presumed to have prevailed. Legislature has made this presumption on its own perception and assessment of the extant standards of political proprieties and morality. At the same time legislature envisaged the need to provide for such "floor crossing" on the basis of honest dissent. That a particular course of conduct commended itself to a number of representatives might, in itself, lend credence and reassurance to a presumption of bona fides. The presumptive impropriety of motives progressively weakens according [to] the numbers sharing the action and there is nothing capricious and arbitrary in this legislative perception of the distinction between 'defection' and 'split' (...)". 48

question about the power of parties. If voters elect their favoured candidate to a seat, is it democratic to allow a party to expel that person and force a by-election if s/he dissents from the party line?"“

A few jurisdictions with list-based systems of proportional representation have permitted a limited right of defection by prescribing that members who defect from the party on whose list they were elected may not join another party, but may only retain their seats as independent members of the legislature.

A.I.R. 1993 SC 412.

48

That the possibility of splits and mergers have to be considered as an important component of parliamentary life under anti-defection regimes is explained by Steytler, Nico, 'Revisiting the anti- 
Consequently, most anti-defection laws distinguish between individual and mass defection, the latter being treated separately in both, South Africa's and India's current floor crossing regulations 49 .

All these distinctions have to be kept in mind when discussing the debate of floor crossing vs. anti-defection laws. For the sake of comparability and simplicity, however, the term defection/floor crossing, in the following, should be understood as including all cases of leaving a particular party after being elected as a legislator on its ticket and joining another party.

There are various ways to approach the phenomenon of floor crossing or defection in parliamentary democracies and to provide analytical categories for a discussion of antidefection legislation. One can start with the potential power-political consequences resulting from defections and argue in (normative) terms of what is the most desired outcome of electoral competition, regime stability and governability viz. majority formation, or a legislative body reflective of the electorate's choice as given at election time. It seems plausible that in both cases floor crossing has to be considered as a serious challenge to these contradicting principles of representative democracy, which are both tied to specific electoral systems, the plurality system and the system of proportional representation and their concomitant rules of decision, a winner-takes-it all logic of electoral competition and one where the respective vote share is decisive ${ }^{50}$.

From a normative perspective however, one could also argue that in a plurality system the latent threat exerted by the possibility of floor crossing compensates for a possible

defection clause', in: Law, Democracy and Development, Vol. 1, November 1997, pp. 227-228, as follows:

"Within the life of a legislature genuine and significant shifts of opinion may occur within and between parties (...) If, during the life of a legislature, these differences in principle or policy become unmanageable, resulting in a split in the party, it seems undemocratic to allow that faction of the party which captures the party machinery to boot the smaller faction out of the party and hence the legislature. A significant fraction of a party can validly claim that it, too, has a mandate from a section of the voters whom it should continue to represent in a legislature."

Additionally, if there is no provision for mergers and splits entailed in anti-defection legislation, then the problem arises that when there is a veritable party split, the two factions are not allowed to pursue legislative work as two separate entities, a fact that makes constructive parliamentary work very unlikely.

Of course, there are many electoral systems that combine elements of both principles of representation and their concomitant rules of decision, as there are systems where the strict adherence to the underlying logic of electoral competition is compromised by all sorts of modifications. As such, the statements about the underlying principles of the two electoral systems in this section have to be seen as based on an idealiter understanding of the two systems and the distinctions made in Table 5 are nowhere that clear-cut in reality. However, the electoral systems in India and South Africa represent the respective 'ends' of the continuum of principles of representation and rules of decision. 
'tyranny' of the majority, an aspect, which is of special importance, since the majorities produced under a plurality system are much more often manufactured than earned ${ }^{51}$. In contrast, anti-defection legislation suits proportional systems much better for it maintains the proportionality of the elected parliament thus guaranteeing that the composition of parliament is reflective of the electorate's will and preventing smaller parties from being wiped out by parties in power enticing members to defect and to join the governing party (additionally, it compensates for the possible instability of coalition governments, which are said to be the likely outcome of proportional representation).

Of course, a constant stream of floor crossing can seriously undermine regime stability and the institutionalisation of the party system and therefore violates the representative principle of majority formation ${ }^{52}$ - as was repeatedly the case in India from 1967 onwards. But, in theory at least, the possibility of floor crossing can act as a counterweight to the danger of a winning party taking the electoral logic of plurality systems too literally ${ }^{53}$.

Table 5: The contradicting principles of idealiter electoral systems in parliamentary democracies

\begin{tabular}{|l|c|c|}
\hline & $\begin{array}{c}\text { plurality system } \\
\text { (constitutency-based) }\end{array}$ & $\begin{array}{c}\text { proportional representation } \\
\text { (list-based) }\end{array}$ \\
\hline principle of representation & majority formation & reflection of electorate \\
\hline rule of decision & winner-takes-it-all & vote share decisive \\
\hline norm of accountability & free mandate & imperative mandate \\
\hline
\end{tabular}

The other and even more fundamental way of conceptualising the debate of floor crossing vs. anti-defection laws, which is again intrinsically tied to the electoral system prevailing in a given polity, is the question of accountability or, to formulate it in another way, to whom is a parliamentarian primarily responsible (or to whom the seat of an elected candidate

The INC, for example, never got more than $50 \%$ of the vote while constantly securing between 70 and $80 \%$ of the seats. On the other hand, however, from the perspective of the winning party, it could be argued, anti-defection legislation compromises the winner-takes-all logic of plurality systems anyway, for it provides opposition parties with a vital shield against 'poaching' MPs from their ranks.

However, if one is to take into account the nature of the party system as intervening variable, then floor crossing may contribute to majority formation in the case a system of one-party dominance prevails, for in one-party-dominant systems in which alternation of government is unlikely, the major incentive of for crossing the floor will be to win higher political office and therefore will take place mainly from smaller parties to the dominant party (see next section).

53 As such, the increase in defections in India from 1967 onwards was brought about by the changing nature of the country's party system. 
'belongs'). In all parliamentary systems there is an irreconcilable tension between multiple responsibilities of the sitting MP: to the voters, to the party, to his/her conscience or, for that matter, to the 'common good'. The basic principle in representative democracy trying to resolve this tension is the decision for or against giving an elected candidate a 'free' or an 'imperative' mandate. In terms of a free mandate, the representative is not bound by any mandate whatsoever, whether originating from the electorate or from the party. He is free to exercise his/her mandate in the national interest and is bound only by his/her conscience. Accordingly, a free mandate and anti-defection legislation are, in principle, antithetical. In contrast, under an imperative mandate representatives are bound by the mandate they received from the electorate and can thus be forced to resign if they cease to be members of the party that nominated them to the legislature.

The legitimation for 'imposing' an imperative mandate on or granting a free mandate to a legislator is again tied to the electoral system prevailing. A key argument of the defenders of anti-defection legislation in South Africa is that in a (closed) list system of proportional representation it is parties that get elected not individual candidates, as would be the case in a constituency system. Consequently, it is the party that is accountable to the electorate and 'owns' the seat and not the individual candidate who has to be considered as a mere unit on a party list. The list party system can therefore be considered as antithetical to the permission of floor crossing. In contrast, a constituency system puts more weight on the representative's individual accountability to the electorate/constituency and gives justification to the representative's right to abandon the party (line) whenever he deems it in the interest of his individual accountability ${ }^{54}$. As such, a constituency-based system like India's would, in theory, be more in accordance with the permission of floor crossing than South Africa's list system.

However, as we have seen in the Indian case, even in a constituency system compatible with a free mandate there is some sort of loyalty or, for that matter, accountability of the individual parliamentarian to the party on whose ticket he or she was elected on the grounds of the electoral, financial or institutional benefits a politician derives from belonging to a party and in terms of parties being "the organising focus of a democratic electoral system" $" 55$ in today's democracies.

In the same vein, even in a list system a representative's accountability to his/her conscience and judgement on behalf of the voters' will (e.g., in the face of changing political

That an individual candidate counts more in a constituency-based system is visible from the number of independents contesting elections in India.

55

Miskin, Sarah, Politician Overboard: Jumping the Party Ship. Research Paper No. 4 (2002-2003) of the Information and Research Services. Australia: Department of the Parliamentary Library, 2003 , p.7. 
conditions), can be considered as above and beyond his/her responsibility to the party/ electorate and a free mandate can therefore be deemed legitimate.

As a norm of accountability concomitant to the respective electoral system the principle of free vs. imperative mandate therefore constitutes something like a grey area.

Finally, another approach to the debate of floor crossing vs. anti-defection legislation in the context of electoral systems could be focused on the aspects of desirability and practicability of anti-defection legislation in terms of the role and power of political parties in a given polity. As already said (leaving intervening factors such as the nature of the political and party system, the position of parties in it as well as the level of party discipline and the (cultural) tradition of party politics aside), proportional list systems put more weight on the party in determining the composition and basic orientation of parliament. The individual parliamentarian is much more dependent on the party because the party leadership is determining his/her list position ${ }^{56}$. An additional anti-defection clause now, strengthens the power of the party even further, for it binds the parliamentarian to the party line under threat of expulsion/losing his/her mandate. ${ }^{57}$ The independence of the individual parliamentarian is thus additionally compromised. On the other hand, parliamentary majority formation - especially in proportional systems said to be prone to producing unstable coalition arrangements - affords a certain level of party cohesion, which ultimately rests on the capacity to enforce party discipline. In constituency-based plurality systems like India's where the individual representative has a direct legitimation and where by-elections are an alternative, an anti-defection regulation would give political parties more power than they justifiably deserve, thus discriminating against the basic value of the electoral system, and can only be upheld normatively because of the institutional desire to create regime stability and/or to introduce a compensation for the winner-takes-all logic of electoral competition.

The normative question involved here is to determine whether a political system accepts the dominating role of political parties in relation to the individual representative.

If the advantages of anti-defection legislation are considered to outweigh its disadvantages in the context of South Africa's list proportional system, what does the Indian experience tell about the practicability of anti-defection legislation? How can it be implemented in a non-discriminatory manner? Can it adequately cover all possible circumstances? Is it possible to design a law, which can, for example, distinguish between 'credible' (resulting from

However, even in constituency-based plurality systems, it is more than often the central party organisation that decides about the individual candidature in a constituency. mandate by means of a by-election. In South Africa, however, by-elections are only permissible at the local level. 
a conflict of conscience) and 'discreditable' (resulting from self-interest), partisan and nonpartisan floor crossing $?^{58}$

The provision in India to leave the decision about disqualification on the grounds of defection to the Speaker, who is dependent on a party for his position, has proved to be problematic. The same holds true for the distinction between individual and en bloc defections, the latter having been more than once subject to partisan engineering. In the same vein, the time requirement (as well as its lifting during the first window periods) and the $10 \%$ provision of South Africa's 'rump' anti-defection regulations are similarly debatable. The problems arising when exploring the practicability and effectiveness of anti-defection legislation are closely tied to the partisan nature of most incidents of floor crossing and attempts at their containment. To gain a first insight into these problems one needs to turn to the specific party system of the two regional contexts, for they can tell something about the interdependence of floor crossing/anti-defection legislation and the party political power configuration prevailing.

In sum, as one can see from the considerations in this section, the question whether floor crossing should be allowed or anti-defection regulations should be imposed in the context of nascent parliamentary democracies is more complicated than expected at first sight. What seems clear is that the decision for a specific electoral system should be seen as a preliminary decision at least as to whether the introduction of anti-defection regulations is appropriate in the given electoral context.

\section{The Politics of Defection: The Importance of the Party System}

The preceding discussion was more or less concerned with the normative aspects involved in the debate about floor crossing vs. anti-defection law with a special emphasis on the electoral context in which this debate is embedded. Now, what about the empirical reality? The problem not touched so far, which is however of special relevance for our regional contexts, is the partisan nature of defections and the question of party politically motivated arguments for and against the permission of floor crossing. While it is almost impossible to draw a line between defections on grounds of conscience or principled disagreements and defections for personal or partisan gain, ${ }^{59}$ or to differentiate between 'honest' and 'dishonest' arguments for and against anti-defection legislation, it is rather obvious as regards the two cases under examination that most cases of defection were based on partisan motives.

As becomes clear from the two regional contexts, even splits or mergers more than often are based on partisan decisions.

59

This holds true for bulk defections as well as is evident, for example, from Chandra Shekar's 'defectors' government' or the NNP's representatives' mass defection. 
And even the introduction of anti-defection regulations in India in 1985 has been criticised on grounds that it was hurriedly enacted without public debate and opposition consultation ${ }^{60}$ and primarily designed in a bid to "erect the kind of walls around the ruling party that its organization had had the strength to generate in the 1960s, but which had wasted away when the organization decayed after $1969^{\prime, 61}$. In a similar vein, the 'quasi-removal' of anti-defection regulations in South Africa is even more of an indication of party elites' manipulative efforts to alter the rules of competition, for the rapprochement between the ANC and NNP in order to overcome the anti-defection clause and to facilitate the forming of an ANC-NNP coalition at the local level and later on at the provincial level is an overt manifestation of this institutional/constitutional change's partisan nature.

So, any discussion of the putative advantages or disadvantages of anti-defection regulations has to take into account the partisan effects this legislation yields, for there is a difference as to who benefits from floor crossing depending on the nature of the party system. The argument put forward here is that the nature and extent of floor crossing and, consequently, the practicability and effectiveness of anti-defection legislation in nascent democracies depend, first of all, on party elites' perception and strategic assessment of the distribution of party political power and the state of parties or, for that matter, the configuration of the party system. Accordingly, anti-defection legislation makes a different sense not only with regard to the electoral regime prevailing in a given context, but also with regard to the distribution of party political power ${ }^{62}$.

Now, coming back to our two empirical cases, we have to address the similarities and differences in their party systems. For most of their post-independent/post-apartheid political development the two countries shared a similar historical outcome as concerns their party systems albeit within very different temporal and spatial contexts: a competitive party system structured around the electoral and ideological dominance of one party that was seen as the primary embodiment of an all-inclusive nationalism.

The problem of floor crossing vs. anti-defection legislation in the context of systems of one-party-dominance thereby involves competing implications: in theory, an anti-defection clause serves the dominant party insofar as it reinforces party discipline and coherence. This was more or less the rationale of Rajiv Gandhi's government's initiative to have parliament enact the Fifty-Second Amendment Act/Tenth Schedule in India in 1985 and -

Gehlot, N.S., 'The Anti-Defection Act, 1985 And The Role Of The Speaker', in: The Indian Journal of Political Science, 52 (1) 1991, p.330. 
according to some observers - also the ANC's hidden agenda when devising the country's electoral system. Thus normatively, permission of floor crossing and a concomitant loosening of the party's grip over its representatives would be a preferable option in a oneparty-dominant context.

However, in practice, floor crossing, combined with a one-party-dominant system, also serves the dominant party. If there is a one-party-dominant system prevailing, the incentive to abandon the dominant party is naturally less attractive than to defect from smaller parties. The advantage of the dominant party in terms of rewarding willing defectors is simply much bigger than the one of smaller (opposition) parties with almost always no chance to take power and office. As Engholm and Mazrui ${ }^{63}$ have shown, the combination of floor crossing and one-party-dominance can produce a centripetal effect in a 'bad' sense: massive floor crossing created several African de facto one-party states in the 1960s before their constitutions changed.

In this vein, the handling of the floor crossing legislation in South Africa is a clear indication that party elites try to ensure that the institutional arrangement of the polity works in favour of the dominant party, which means that there are (institutional) guarantees that the dominant party is in a position to play its organisational advantage and electoral dominance off against opposition parties. ${ }^{64}$ So, the $10 \%$ requirement of the current arrangement ensures that "whereas a single member of any of the parties with less than ten MPs could defect (...) at least twenty-seven MPs would have to conspire to defect (as a bloc) from the $\mathrm{ANC}$, with all the attendant risk of exposure and expulsion if the attempt were to fail" The ANC, cognisant of the fact that its dominant position would last into the foreseeable future, became aware that permission of floor crossing and the concomitant politics of defection would by far outweigh the advantage of the anti-defection clause.

Similarly, the INC was the net gainer of defections during the heyday of one-party-dominance in India. When there were first signs of electoral weakness after 1967 and it became clear that in the States at least, there was a real chance of toppling Congress-governments thus gaining access to state office and patronage, more defectors flowed out of Congress than in. But why did the Congress not recover from this "defectors market",66, why did

Engholm, G. and Ali Mazrui, 'The tensions of crossing the floor', in: Mazrui, Ali (ed.). Violence and Thought: Essays in Social Tensions in Africa. London, 1969. tion), 30, April 2003, p. 35, available online at: www.hsf.org.za/focus30/focus30myburgh.html. An even more unequal ratio applies in the context of India's anti-defection law.

Morris-Jones, W.H., 'From Monopoly to Competition in India's Politics', in: Morris-Jones, W.H., Politics Mainly Indian. Madras, 1978, p.155. 
defections become so routinised in Indian party politics ${ }^{67}$ that, as Kashyap wrote, “(...) nobody takes notice of them, they no more "make news",68 - given the fact that the INC's electoral dominance was far from over in 1967.

In this regard, the specific nature of Congress' dominance has to be addressed as well. It was based on factionalism and accommodation, a high degree of internal pluralism and a pragmatic rather than ideological orientation. As long as the INC was able to uphold its intricate structure of internal pluralism and factional balance, defections represented no serious problem. It is therefore no wonder that defections gained serious proportions when India's party system experienced the first traces of electoral uncertainty, when the "(...) emergence of a 'market type' polity" ${ }^{\text {"69 }}$ set in and the Congress' dominance changed quality. ${ }^{70}$ From then on the politics of defection gained momentum culminating in the period of unstable coalition politics characterising the Indian party system for nearly 20 years now ${ }^{71}$.

So, paradoxically, the danger of allowing unhindered floor crossing involves another aspect apart from the centripetal one in the context of one-party-dominance mentioned above: If there is no dominant party available, which is able to contain defections and/or give them direction, the politics of defection may seriously threaten the further institutionalisation of the party system (and may lead nascent democracies to the brink of collapse).

Kashyap, Subhash, The Politics of Power. Defections and State Politics in India (revised and edited by Savita Kashyap), Delhi, 1974, p.30.

The 'ideological pragmatism' of the Congress thereby has to be seen as rather ambivalent. As Singh (1981: 28) notes on Congress' pragmatism: "While pragmatism of its leaders helps the predominant party to make, with relative ease, compromise on policies and tactics, it works as a double-edged sword. For if the loyalty of party activists to the party organization comes under serious strain in times of crisis (e.g., loss of predominance in electoral competition), members do not feel constrained by the ideological bonds to the party, at any rate to the same extent as members of more doctrinaire parties. Consequently, in such circumstances the party becomes vulnerable to massive defections and schisms (...)." In the same vein, Manor (Manor, James, 'Parties and the Party System', in: Kohli, Atul (ed.), India's Democracy: An Analysis of Changing State Society Relations. Princeton, 1988, p. 70) comes to the conclusion that “(...) the highly disciplined, ideologically oriented parties of the Marxist left and the Hindu chauvinist right remained almost entirely immune to this new trend [of defections after 1967]." anti-defection law - is an indication that the party organisation of the INC had never regained its strength after the decay in 1967/69 and confirms the exceptionalism of Rajiv Gandi's electoral victory as noted by most observers. 
In sum, the one 'lesson' South Africa can learn from India is that if the ANC ceases to be the dominant party, the politics of defection may get off the rail ${ }^{72}$. Thus, the short-term partisan gain incurred by the ANC's manoeuvre to overcome the anti-defection clause may bounce back and floor crossing may become a serious problem for the further institutionalisation of the country's party system. In this case - as becomes evident from the Indian experience - even anti-defection legislation may prove to be unworkable or problematic at best. However, and that should be kept in mind with the regard to the electoral reform debates going on in both countries, if the South African democracy's rationale is equally bound by national integration as it is by regime stability - the former being highlighted by the choice of proportional representation - an anti-defection clause may be much more compatible with the electoral regime and configuration of the country's party system anyway.

In India the anti-defection regulations may be rightfully upheld for the sake of regime stability while, in principle, violating the constituency-based plurality system. But to minimise partisan instrumentalisation of the anti-defection regulations the 'Speaker provision' and the distinction between individual and en bloc defections would have to be redefined.

In both countries the justification of anti-defection legislation was advanced on the basis of two differing principles - majority formation and proportional representation. So, ultimately, the question whether floor crossing should be allowed or anti-defection regulations should be imposed, rests on the configuration of the party system and the crucial dilemma of what has to be considered more important in the context of nascent democracies and divided societies: regime stability or national integration. 